\title{
Ultrastructure of the ovarian follicles, oviducts and oocytes of Gyrocotyle urna (Neodermata: Gyrocotylidea)
}

\author{
Larisa G. Poddubnaya ${ }^{1}$, Roman Kuchta ${ }^{2}$, Tomáš Scholz ${ }^{2}$ and Willi E.R. Xylander ${ }^{3}$ \\ ${ }^{1}$ Institute of Biology of Inland Waters, Russian Academy of Sciences, 152742 Borok, Yaroslavl Province, Russia; \\ ${ }^{2}$ Institute of Parasitology, Biology Centre of the Academy of Sciences of the Czech Republic, Branišovská 31,37005 České \\ Budějovice, Czech Republic; \\ ${ }^{3}$ Senckenberg Museum für Naturkunde Görlitz, Postfach 300 154, 02806 Görlitz, Germany
}

\begin{abstract}
An ultrastructural study of the ovarian follicles and their associated oviducts of the cestode Gyrocotyle urna Grube et Wagener, 1852, a parasite from the spiral valve of the rabbit fish, Chimaera monstrosa L., was undertaken. Each follicle gives rise to follicular oviduct, which opens into one of the five collecting ducts, through which pass mature oocytes. These collecting ducts open into an ovarian receptacle which, in turn, opens via a muscular sphincter (the oocapt) to the main oviduct. The maturation of oocytes surrounded by the syncytial interstitial cells within the ovarian follicles of $G$. urna follows a pattern similar to that in Eucestoda. The ooplasm of mature oocytes contain lipid droplets $(2.0 \times 1.8 \mu \mathrm{m})$ and cortical granules $(0.26 \times 0.19 \mu \mathrm{m})$. The cytoplasm of primary and secondary oocytes contains centrioles, indicating the presence of the so-called "centriole cycle" during oocyte divisions. A morphological variation between different oviducts was observed. The luminal surface of the follicular and the collecting oviducts is smooth. The zones of the septate junctions are present within the distal portion of the net-like epithelial wall of the collecting ducts close to the ovarian receptacle. The syncytial epithelial lining of the ovarian receptacle, oocapt and main oviduct is covered with lamellae and cilia. Cortical granules secreted from mature oocytes occur freely within the lumen of the main oviduct that functions as a fertilisation canal. A division of the ovary into separated parts with their own collecting ducts as that typical of Gyrocotyle has been observed in neodermates, basal monogenean family Chimaericolidae, and Neoophora (some Proseriata and Fecampiidae). Ultrastructural data thus reveal several unique morphological characteristics of gyrocotylideans, the most basal taxon of tapeworms (Cestoda).
\end{abstract}

Keywords: Platyhelminthes, comparative morphology, TEM, ovary, oocapt, ovarian receptacle, fertilisation canal

Detailed ultrastructural studies of the ovary and oogenesis have only been carried out for a few groups of parasitic neodermate flatworms: Digenea (Björkman and Thorsell 1964, Gresson 1964, Holy and Wittrock 1986, Orido 1987, 1988, Cifrian et al. 1993, Podvyaznaya 2003), Monogenea (Halton et al. 1976, Tappenden et al. 1993) and Eucestoda (Davies and Roberts 1983, Poddubnaya et al. 2005a, 2007). Light microscopical studies on tapeworm oogenesis and embryogenesis were presented by Douglas (1963) and Rybicka (1967). The ultrastructure and composition of the ovary of the Gyrocotylidea, the most basal group of tapeworms (Cestoda) (Olson et al. 2001, Lockyer et al. 2003, Waeschenbach et al. 2007), have not yet been studied. In recent years, new ultrastructural features of the Gyrocotylidea indicate their key position in terms of the evolution of the Neodermata (Xylander 2001, 2005, Poddubnaya et al. 2006, 2008, 2009, Xylander and Poddubnaya 2009).
Therefore, the aims of the present study are: (1) to investigate the ultrastructure of the ovarian follicles and associated oviducts of Gyrocotyle urna; and (2) to compare these structures with those of other female gonads at the neoophoran level of organisation in platyhelminths, focusing on possible affinities with neodermates.

\section{MATERIALS AND METHODS}

Specimens of Gyrocotyle urna were removed from the spiral valve of several specimens of the rabbit fish, Chimaera monstrosa L., caught in the North Sea off Bergen, Norway; other specimens of G. urna were obtained from the same host in Oslo Fjord near Moss.

The worms obtained from the Oslo Fjord were prepared for transmission electron microscopy as described previously (Xylander 1987). Other specimens obtained from the North Sea off Bergen were fixed with $5 \%$ glutaraldehyde in $0.1 \mathrm{M}$ sodium cacodylate buffer ( $\mathrm{pH} 7.2$ ) for 40 days at $5{ }^{\circ} \mathrm{C}$, rinsed 4 times in the same buffer for $20 \mathrm{~min}$ and postfixed in $1 \%$ osmium tetroxide 
for $1 \mathrm{~h}$. Specimens were then dehydrated in a graded series of ethanol and acetone, and embedded in mixture of Araldite and Epon. Ultrathin sections were stained with uranyl acetate and lead citrate, and examined using a JEOL JEM-1011 transmission electron microscope operating at $80 \mathrm{kV}$.

For histological observations, some specimens were fixed with hot $4 \%$ formaldehyde solution, dehydrated through an ethanol series and embedded in paraffin. Serial sections (thickness $12 \mu \mathrm{m}$ ) were stained with haematoxylin and eosin, then mounted in Canada balsam and examined using an Olympus BX-51 microscope.

\section{RESULTS}

\section{Ovary}

The ovary of Gyrocotyle urna is composed of many isolated ovarian follicles arranged in a horseshoe-shaped cluster and located in the third quarter of the worm's body. Each follicle gives rise to a tubular follicular oviduct (Figs. 1-3), which opens into one of five collecting oviducts (one posteriorly, two laterally and two anteriorly) through which the mature oocytes from all of the ovarian follicles pass. These five ducts open into a common ovarian receptacle (Fig. 1), which is quite large, and opens ventrally alongside the median line via a muscular sphincter (oocapt) into main oviduct, which acts as the fertilisation canal (Fig. 1).

\section{Epithelium of follicles}

Each ovarian follicle is enveloped by a compressed epithelial sheath lying on the basal matrix (Figs. 6, 7, 9, 10). The epithelial nuclei are located close to the base (proximal or basal part) of the follicular oviduct (Fig. 5). The nuclei contain patches of peripheral and central heterochromatin, and the epithelial cytoplasm around every nucleus is filled with ribosomes and isolated mitochondria (Fig. 5). The luminal surface area of this epithelial region is increased by narrow luminal processes (Fig. 6).

\section{Interstitial syncytium}

The intercellular spaces between the tightly packed oocytes are filled with the processes of interstitial cytoplasm (Fig. 7). The interstitial nuclei are usually located in the peripheral area of the follicle (Fig. 7). They contain significant patches of heterochromatin. The long, flattened cytoplasmic processes contain mitochondria, a few short cisternae of granular endoplasmic reticulum (GER), myelin-like bodies and large, irregularly shaped accumulations of moderately electron-dense homogeneous material (Figs. 7, 8).

\section{Germ cells in ovarian follicles}

Every follicle contains numerous oocytes at different stages of maturation (Fig. 4) and of continuously increasing size. Simultaneously, the oocytes undergo character-

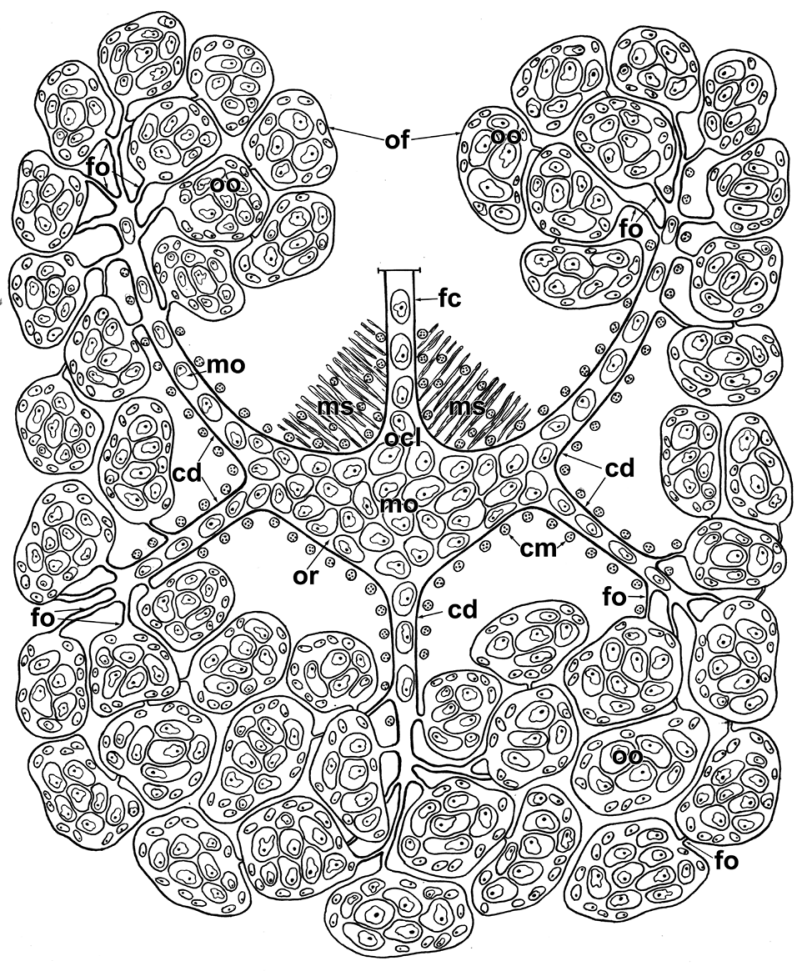

Fig. 1. Diagram of the arrangement of the isolated ovarian follicles and associated oviducts in Gyrocotyle urna. Abbreviations: $\mathrm{cd}$ - collecting duct; $\mathrm{cm}$ - circular muscles; fc - fertilisation canal; fo - follicular oviduct; mo - mature oocytes; ms - muscular sphincter; ocl - oocapt lumen; of - ovarian follicles; oo-oocytes; or - ovarian receptacle.

istic cytological changes, which enable differentiation of distinct stages of their maturation. The electron density of the cytoplasm of some oocytes is much greater than in others, probably indicating the presence of higher numbers of ribosomes within the cytoplasm (Figs. 4, 8). Oocytes are closely packed within the follicles and are often hexagonal in outline (Figs. 4, 8). Their plasma membrane is generally smooth (Figs. 8, 9, 12, 13).

\section{Oogonia}

The oogonia $(6.5 \times 4.5 \mu \mathrm{m})$ are characterized by a relatively small nuclear-cytoplasmic ratio and by a large nucleus containing dense chromatin patches. They are located in the peripheral regions of the follicles. Their electron-dense cytoplasm is filled with ribosomes (Fig. 9).

\section{Primary oocytes}

The earliest stages of differentiating oocytes are located in close vicinity to the follicular epithelium (Figs. 7, $11)$. These cells are relatively small $(8 \times 5 \mu \mathrm{m})$ and have a large nucleus with or without a prominent nucleolus. Their cytoplasm is packed with free ribosomes and contains mitochondria (Figs. 7, 11). A centriole is present 

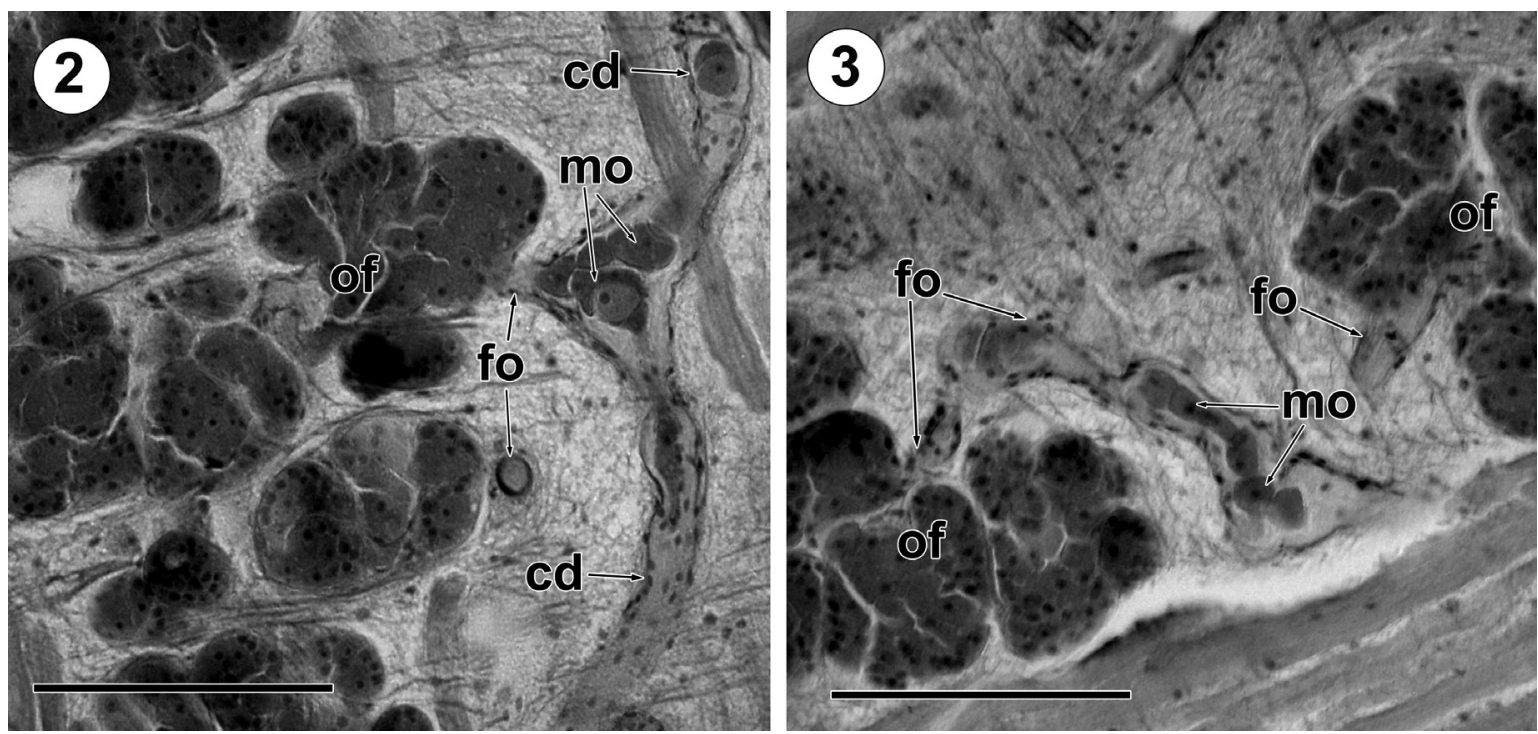

Figs. 2, 3. Histological sections of the ovarian follicles and their oviducts of Gyrocotyle urna. Fig. 2. Part of the ovarian follicle showing its duct and portion of a collecting duct. Fig. 3. Portions of two ovarian follicles with their own follicular oviduct. Abbreviations: cd - collecting duct; fo - follicular oviduct; mo - mature oocytes; of - ovarian follicle. Scale bars: Fig. $2=80 \mu \mathrm{m}$; Fig. $3=100 \mu \mathrm{m}$.

within the cytoplasm of this stage (Figs. 11, 15). During the growth of the oocytes, the number of mitochondria and the volume of the cytoplasm increase.

\section{Secondary oocytes}

Maturing oocytes are larger and measure $11-16 \mu \mathrm{m}$ in length and 7-8.5 $\mu \mathrm{m}$ in width (Fig. 12). Mitochondria, granular endoplasmic reticulum and Golgi complexes are found throughout the cytoplasm (Fig. 14). Different number of centrioles can be observed within the cytoplasm (Figs. 16, 18). The most striking feature of these cells, however, is the appearance of homogeneous electron-dense granules inside small vesicles arising from the Golgi complexes deeply within the cytoplasm (Figs. 12, 14). The synaptonemal complexes appear within the oocyte nucleus during further oocyte development (Figs. 12, 17). Larger maturing oocytes $(17-19 \times 9-12$ $\mu \mathrm{m}$ in diameter) are characterized by a greater number of mitochondria, cisternae of GER, Golgi complexes, a further accumulation of electron-dense granules, and few lipid droplets (Fig. 13).

\section{Mature oocytes}

Mature oocytes are about $20-26 \times 12-17 \mu \mathrm{m}$ in size. They are located more centrally within the ovarian follicles. Their nucleus contains a well-defined nucleolus and there are no synaptonemal complexes (Fig. 19). Two types of inclusions are most abundant in their ooplasm: small electron-dense, slightly oval cortical granules $(0.26$ $\times 0.19 \mu \mathrm{m}$ ), which form a continuous monolayer within the cortical ooplasm; and a few spherical or slightly oval lipid droplets $(2.0 \times 1.8 \mu \mathrm{m})$ (Figs. 19, 21).

\section{Follicular oviduct}

A single duct arises from each ovarian follicle and its lumen is filled with mature oocytes (Figs. 1-3, 21). The electron-lucent epithelial lining of these ducts is deeply penetrated by numerous long, branched invaginations of the basal plasma membrane (Fig. 22), along which small islets of electron-dense cytoplasm filled with free ribosomes, mitochondria and sparse GER are present. The epithelial nuclei are flattened, exhibit chromatin patches and are scattered along the basal and middle portions of epithelial lining. Nuclei are surrounded by a narrow area of electron-dense cytoplasm (Fig. 22). The ducts are enclosed by a basal matrix continuous with that of the ovarian follicles and, peripherally, by circular muscles (Fig. 22). Mature oocytes within the lumen of the follicular oviducts are usually arranged in a single or double row. Most of their cortical granules are immediately adjacent to the oocyte plasma membrane.

\section{Main collecting ducts}

The epithelial wall of five collecting oviducts (Figs. 1, 2,24 ) has the same ultrastructural morphology as that of the follicular oviducts. Numerous septate junctions are present within the distal portions of the net-like epithelial wall of these ducts, close to the ovarian receptacle (Figs. 23, 26, 27). Three, four or more tightly packed mature oocytes may be located side by side within the lumen of the ducts (Fig. 24).

\section{Ovarian receptacle}

The ovarian receptacle represents an enlarged reservoir for germ cells and collects mature oocytes from the five 

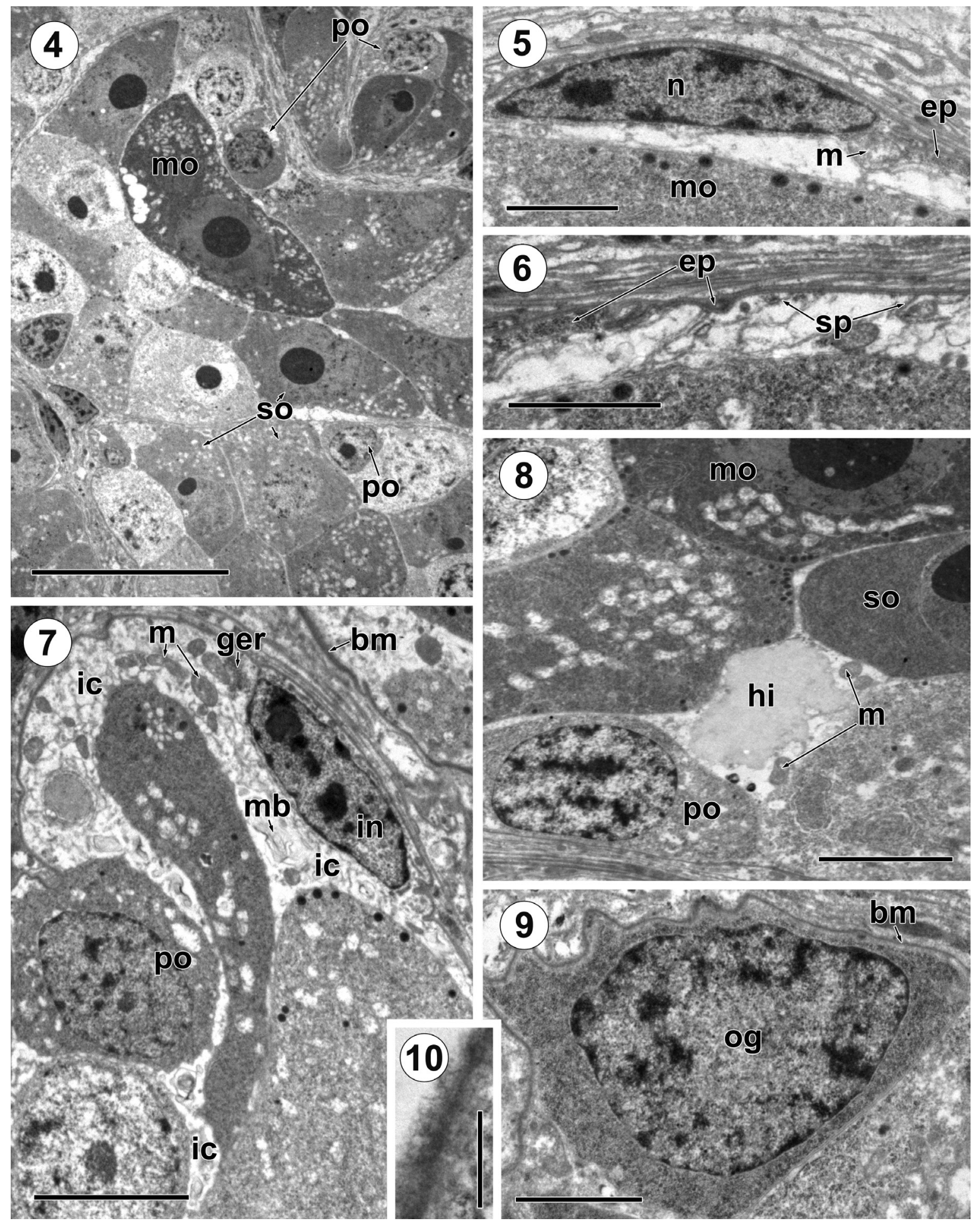

Figs. 4-10. Ultrastructure of the follicle epithelium, interstitial tissue and oogonia of Gyrocotyle urna. Fig. 4. Detail of the follicular area with oocytes at different stages of maturation; note the different cytoplasmic densities of the oocytes. Fig. 5. Epithelial nucleus of the ovarian follicle near the follicular oviduct. Fig. 6. Narrow surface processes of the epithelial lining near the follicular oviduct. Fig. 7. Portion of the ovarian follicle showing a peripheral interstitial nucleus, the cytoplasmic projections of which are visible between oocytes. Fig. 8. Large homogeneous inclusion within the interstitial cytoplasm. Fig. 9. Oogonia located along follicle sheath. Fig. 10. Basal matrix of the ovarian follicle. Abbreviations: bm - basal matrix of the ovarian follicles; ep - epithelium; ger - granular endoplasmic reticulum; hi - homogeneous inclusion of interstitial cytoplasm; ic - interstitial cytoplasm; in - interstitial nucleus; $\mathrm{m}$ - mitochondria; $\mathrm{mb}$ - myelin-like bodies; mo - mature oocyte; $\mathrm{n}$ - nucleus; og - oogonia; po - primary oocyte; so - secondary oocyte; sp - surface projections of the follicular epithelium. Scale bars: Fig. $4=20 \mu \mathrm{m}$; Figs. 5, 6, $9=2 \mu \mathrm{m}$; Figs. 7, $8=5 \mu \mathrm{m}$; Fig. $10=1 \mu \mathrm{m}$. 

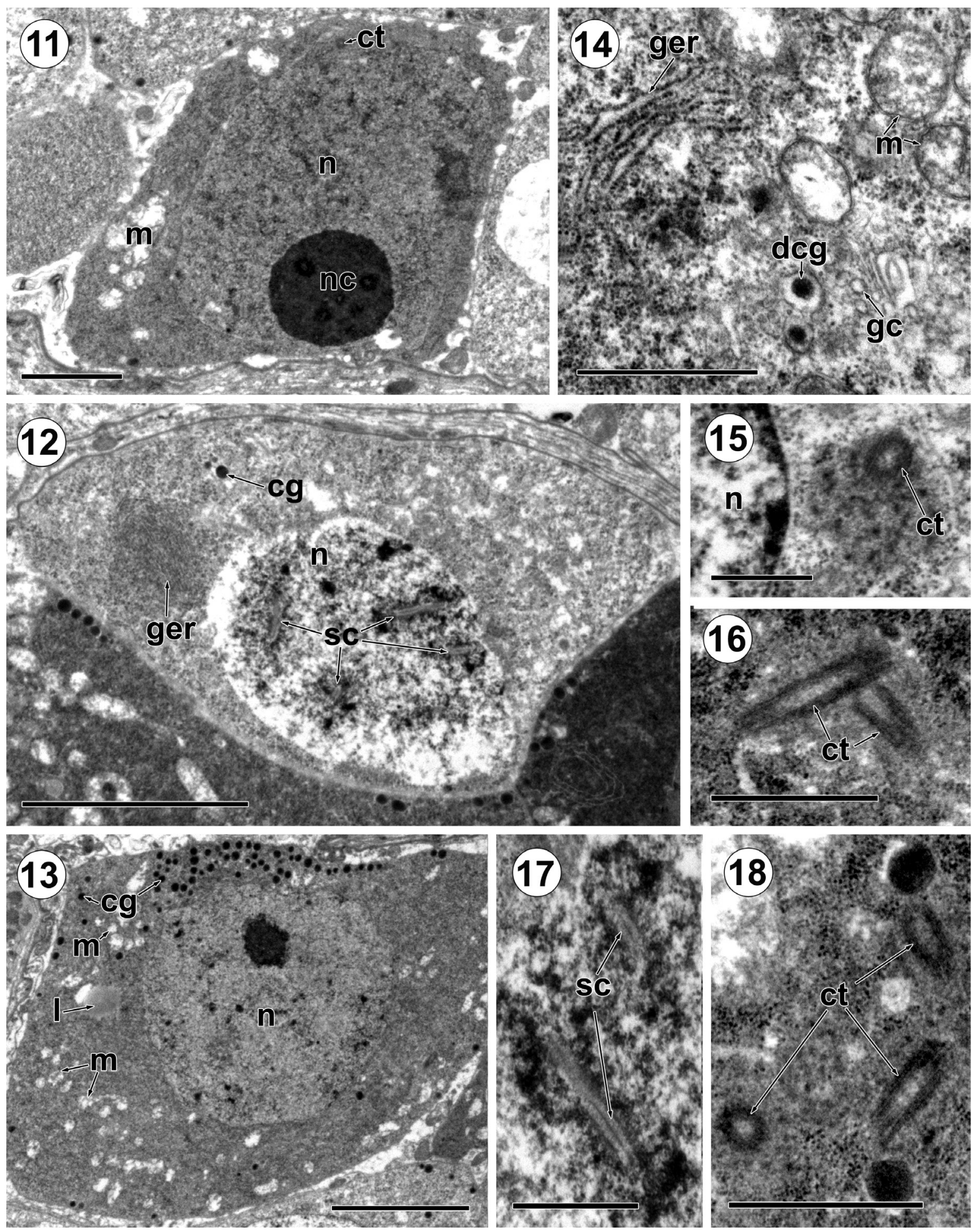

Figs. 11-18. Ultrastructure of the primary and secondary oocytes of Gyrocotyle urna. Fig. 11. Primary oocyte, showing mitochondria and one centriole within the ooplasm; note the well-developed nucleolus within the nucleus. Fig. 12. Secondary oocyte; note an accumulation of parallel GER cisternae and few electron-dense granules in the cytoplasm; four synaptonemal complexes are visible in the nucleus. Fig. 13. Larger oocyte with numerous mitochondria, an accumulation of cortical granules and the appearance of single lipid droplet within the cytoplasm. Fig. 14. Ooplasm showing Golgi complex vesicles with electron-dense granules inside, GER cisternae and mitochondria. Fig. 15. Centriole within the ooplasm of primary oocytes. Fig. 16. Two centrioles within the ooplasm of secondary developing oocyte. Fig. 17. Synaptonemal complexes with the characteristic tripartite structure in the nucleus of secondary oocyte. Fig. 18. Ooplasm of secondary oocytes showing three centrioles. Abbreviations: cg - cortical granules; ct - centriole; dcg - developing cortical granule; gc - Golgi complex; 1 - lipids; $\mathrm{m}$ - mitochondria; $\mathrm{n}$ - nucleus; $\mathrm{nc}$ - nucleolus; ger - granular endoplasmic reticulum; sc - synaptonemal complex. Scale bars: Fig. $11=2 \mu \mathrm{m}$; Figs. 12, $13=5 \mu \mathrm{m}$; Figs. 14, 15, $18=0.5 \mu \mathrm{m}$; Figs. $16,17=1 \mu \mathrm{m}$. 
collecting ducts (Fig. 1). The epithelial lining of the ovarian receptacle is characterized by the presence of two types of apical structures on the luminal surface: lamellae and cilia (Fig. 25). The nuclei are located within epithelium of the ovarian receptacle and there are numerous invaginations of the basal membrane that may reach the luminal surface (Fig. 25).

\section{Oocapt and main oviduct (fertilisation canal)}

A muscular sphincter (oocapt) surrounds the junction between the ovarian receptacle and the distal oviduct. It is characterized by a well-developed, closely packed musculature beneath the oocapt epithelium (Fig. 29). The latter is a prolongation of the epithelium of the ovarian receptacle and has the same structure (Figs. 1, 25). The luminal wall of the oocapt and distal oviduct (or fertilisation canal) bears cilia and lamellae along its length (Figs. 28, 31,32 ). Free cortical granules can be observed within the lumen of this duct (Figs. 30, 31).

\section{DISCUSSION}

\section{Comparison of the anatomical features of the ovary and its associated oviducts in neoophorans}

The present investigation shows the division of the ovary of Gyrocotyle urna into isolated follicles and an unusual pattern of multiple 'oviducts', referred to by us as 'the follicular oviducts', five 'collecting ducts', 'the ovarian receptacle', an oocapt and 'the main oviduct' (or fertilisation canal). The same pattern of the ovary and its collecting ducts has previously been described in light microscope studies by Watson (1911) and Lynch (1945) for Gyrocotyle fimbriata Watson, 1911 and G. urna. The division of the ovary of Gyrocotyle into separate follicles with their own oviduct was also noted by Fuhrmann (1931), and the presence of an ovarian receptacle in gyrocotylidean species has also been mentioned by Joyeux and Baer (1950). Thus, the present work provides the first ultrastructural data on gyrocotylidean ovarian follicles and multiple connecting ducts of G. urna.

The division of the ovary and the arrangement of associated ducts observed in gyrocotylideans have been reported previously among platyhelminths for the basal monogenean genus Chimaericola (Bychowsky 1957). All other neodermates possess a single ovary with a single oviduct. For example, in "true" tapeworms (Eucestoda) the female reproductive system has a single lobed, bilobed or multilobed ovary, which may differ in size and shape, and may be compact or diffuse; mature oocytes leave the ovary via a single oviduct (Wardle and McLeod 1952, Schmidt 2000). In some polyzoic, strobilized tapeworms, with a doubling of the reproductive organs, two ovaries occur within a single segment (Schmidt 2000). In some caryophyllideans (monozoic tapeworms) and both- riocephalideans (polyzoic tapeworms) the ovary may be divided by numerous deep invaginations of its epithelial sheath, it may give the appearance of being follicular, but the ovarian lobes are united by a narrow isthmus (Mackiewicz 1972, Campbell and Gartner 1982).

Variation in ovarian shape (bilobed or coarsely or finely lobed, or lobate, or smooth and irregularly-shaped with rough surface) has been mentioned for the Amphilinidea by Dubinina (1982) and Bandoni and Brooks (1987). In Amphilina bipunctata Riser, 1948, the ovary has 8-10 irregular, digitiform processes which extend laterally and anteriorly from a central core (Coil 1987).

Most species of the Monogenea (excluding members of the basal family Chimaericolidae) and, in the vast majority of the cases, the Digenea (part of the Trematoda) are characterized by a single ovary which can differ in the shape and size and is connected to a single oviduct (Bychowsky 1957, Gibson 1996, Conn 2000, Galaktionov and Dobrovolskij 2003).

In neoophorans, most members of the Rhabdocoela also have a single ovary (Falleni and Lucchesi 1992, Lucchesi et al. 1995, Falleni et al. 1998). Most species of the Proseriata possess ovaries with several germ cells at different stages of maturation (Gremigni and Nigro 1984, Gremigni 1988), but proseriates of the families Nematoplanidae, Polystyliphoridae and Otoplanidae possess two to six pairs of ovarian follicles and each of them is connected via a short oviduct to a common ovovitelloduct (Sopott-Ehlers 1986, 1991, Falleni and Gremigni 1992). Paired ovaries have also been found in Kronborgia isopodicola Blair et Williams, 1987 (Fecampiidae), a flatworm with an endoparasitic phase of life (Williams 1989).

\section{Components of the ovary of Neodermata}

The maturation of oocytes of G. urna follows the pattern described in the other neodermates. They increase in size and change their cytological characteristics from poorly differentiated cells (oogonia and primary oocytes) to secondary and mature oocytes. Secondary oocytes are characterized by synaptonemal complexes in the nucleus, and their subsequent disappearance is typical in mature oocytes, indicating that the oocytes enter the diplotene phase while still in the ovary (Holy and Wittrock 1986). The development of GER and Golgi complexes within the cytoplasm of growing oocytes is a result of the production of electron-dense granules and lipid droplets and the subsequent migration of these granules to the cortical ooplasm, where they form a continuous monolayer. Oocytes of many neodermates contain cytoplasmic inclusions, such as lipids and cortical granules. The structure of the cortical granules has been shown to be useful in phylogenetic studies of the Platyhelminthes (Sopott-Ehlers 1991). Small cortical granules (less than $0.3 \mu \mathrm{m}$ ) are present in the Digenea, Aspidogastrea (both groups form Trematoda), Gyrocotylidea and Eucestoda (Cestoda) 

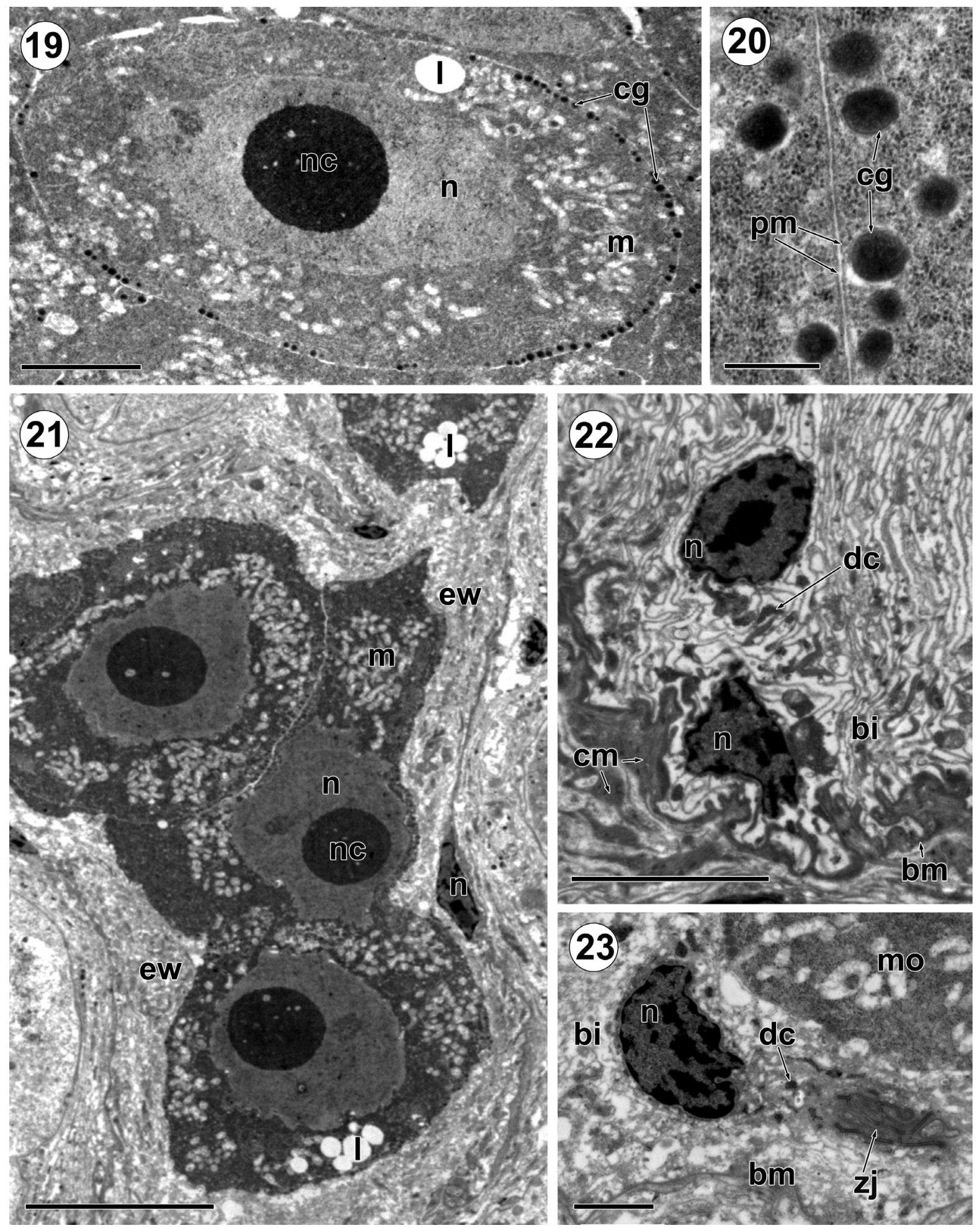

Figs. 19-23. Ultrastructure of the mature oocytes and follicle ducts of Gyrocotyle urna. Fig. 19. Mature oocyte showing nucleus with well-defined nucleolus, abundant mitochondria, lipid droplets and peripheral monolayer of cortical granules. Fig. 20. Cortical granules within outer cytoplasm of two adjacent mature oocytes in the ovarian follicles. Fig. 21. Mature oocytes within lumen of the follicular oviduct. Fig. 22. Portion of the epithelial wall of the follicular oviduct; note two nuclei and deep invaginations of the basal membrane of the duct epithelium. Fig. 23. Portion of the epithelial wall of the collecting duct showing zone of the septate junctions. Abbreviations: bi - basal invaginations; bm - basal matrix; cg - cortical granules; cm - circular muscles; dc - dense cytoplasm; ew epithelial wall; 1 - lipids; $\mathrm{m}$ - mitochondria; mo - mature oocyte; $\mathrm{n}$ - nucleus; $\mathrm{nc}$ - nucleolus; $\mathrm{pm}$ - plasma membrane; $\mathrm{zj}$ - zone of septate junctions. Scale bars: Figs. 19, $22=5 \mu \mathrm{m}$; Fig. $20=0.5 \mu \mathrm{m}$; Fig. $21=10 \mu \mathrm{m}$; Fig. $23=2 \mu \mathrm{m}$. 
(Hathaway 1979, Justine and Mattei 1984, Grant et al. 1977, Cifrian et al. 1993, Poddubnaya et al. 2007, present study).

Different number of centrioles and their arrangement, as found in the ooplasm of different stages of oocyte maturation in G. urna, has been reported only exceptionally for platyhelminths and the presence of the centrioles within the ooplasm has only been noted for two digenean species (Erasmus 1973, Awad and Probert 1990). Centrioles are typical organelles in animal cells and the difference in their number and arrangement is a result of their so-called "centriole cycle" during mitotic division (Swanson and Webster 1980, Zavarzin and Kharasova 1982). The study of oogenesis in Amphilina bipunctata has also revealed the presence of centrioles at different stages of their development (formation) within the oocytes (Poddubnaya and Xylander, unpublished data).

In addition to the germinal components, syncytial interstitial tissue is present in the ovarian follicles, the cytoplasm of which fills the spaces between the oocytes in G. urna. Such interstitial cells are known from different organs of neodermates and are supposed to be responsible for the transport of nutrients and energy sources (Gresson 1964, Orido 1987, Conn 1993, Świderski and Xylander 2000, Podvyaznaya 2003, Poddubnaya et al. 2005a, 2007, Conn et al. 2009). Agglomeration of large homogeneous inclusions within follicular space of G. urna has not been observed in other neodermates; their nature and function are unclear. It should also be noted that G. urna may survive in its definitive host for many years and possibly for as long as the fish survives (Dienske 1968, Land and Templeman 1968, Allison and Coakley 1973).

\section{Ultrastructural characters of the oocapt and oviduct in Neodermata}

In neodermates the oocytes are usually transported from the ovary to the oviduct through the oocapt, the epithelial wall of which is a prolongation of the ovarian epithelium; numerous muscle bundles are present beneath this epithelium. Thus, the oocapt represents a muscular sphincter. Its ultrastructure has been investigated in digeneans, monogeneans and cestodes (Gupta et al. 1983, ElNaggar et al. 1990, Podvyaznaya 1990, 2003, Davydov et al. 1994, Galaktionov and Dobrovolskij 2003, Poddubnaya et al. 2007). Another structure of the oocapt, a syncytial cell which blocks the lumen and controls the passage of mature oocytes into the oviduct, has been observed in the monogenean Entobdella soleae Beneden et Hesse, 1864 (see Tappenden et al. 1993) and in the spathebothriidean cestode Cyathocephalus truncatus (Pallas, 1781) (see Poddubnaya et al. 2005b).

In G. urna, however, the muscular sphincter (oocapt) is situated between the ovarian receptacle and the distal portion of the oviduct. Oocytes develop asynchronously within the ovarian follicles of G. urna and mature oocytes apparently pass into the follicular oviducts without any special regulation, their passage being restricted only as they pass from the ovarian receptacle into the main oviduct. Light microscopical studies on Gyrocotyle by Watson (1911) and Lynch (1945) showed that this main oviduct, immediately distal to the ovarian receptacle, which receives a short duct from the seminal receptacle, functions as a fertilisation canal. Our data support this assumption because most cortical granules of G. urna are close to or in direct contact with the oolemma of mature oocytes located within the lumen of the follicular oviducts, the five collecting ducts and ovarian receptacle, but they are free in the lumen of the main oviduct distal to the muscular sphincter. Cortical granules play a crucial role in the so-called "cortical reaction" and are considered to prohibit polyspermy in some animals (Tyler 1965, Guraya 1969, Grey et al. 1976, Świderski 1976, Świderski and Conn 1999, Świderski et al. 2004). It is likely that the muscular sphincter controls in G. urna the passage of mature oocytes from the ovarian receptacle into the fertilisation canal.

Our study has shown that the oviduct of Gyrocotyle is represented by multiple ducts that form an ovarian receptacle for mature oocytes prior to forming the fertilisation canal. The morphology of the epithelium of both the follicular oviducts and the collecting oviducts of G. urna differs from that previously observed in other Neodermata. The epithelial wall of these ducts resembles an aggregation of thin, branching processes with nuclei scattered between them. Indeed, the basal plasma membrane of the epithelium, resting on the basal matrix, forms deep invaginations into the electron-lucent epithelial cytoplasm of the ducts, and nuclei and small, electron-dense cytoplasmic areas occur only alongside their length. The luminal surface of the follicular oviducts and the collecting oviducts is smooth. A similar structure of the epithelial wall of the oviduct (or ovovitelline duct for fecampiids) has been observed in Kronborgia isopodicola by Williams (1990), who indicated that this wall of unusual structure is "composed of intricately interdigitating processes and nuclei are rarely encountered" (Williams 1990, p. 962).

The epithelial surface of the collecting oviducts close to the ovarian receptacle, as well as the surface of the ovarian receptacle, oocapt and fertilisation canal, is covered with lamellae and cilia. Large zones of septate junctions have been observed within the epithelial lining of the distal portions of the collecting ducts of G. urna. However, a syncytial and lamellate structure of the oviduct lining is found in the Eucestoda and Monogenea (El-Naggar et al. 1990; see review of the oviduct structure in eucestodes by Poddubnaya et al. 2005b). The oviduct of the Digenea is characterized by a lamellate and ciliated surface and there are contact zones between its epithelial cells (Erasmus 1973, Rees 1979, Thulin 1982, Podvyaznaya 2003). Therefore, the present data show that the ultrastructure of the lining of the multiple parts of the oviduct of G. urna 

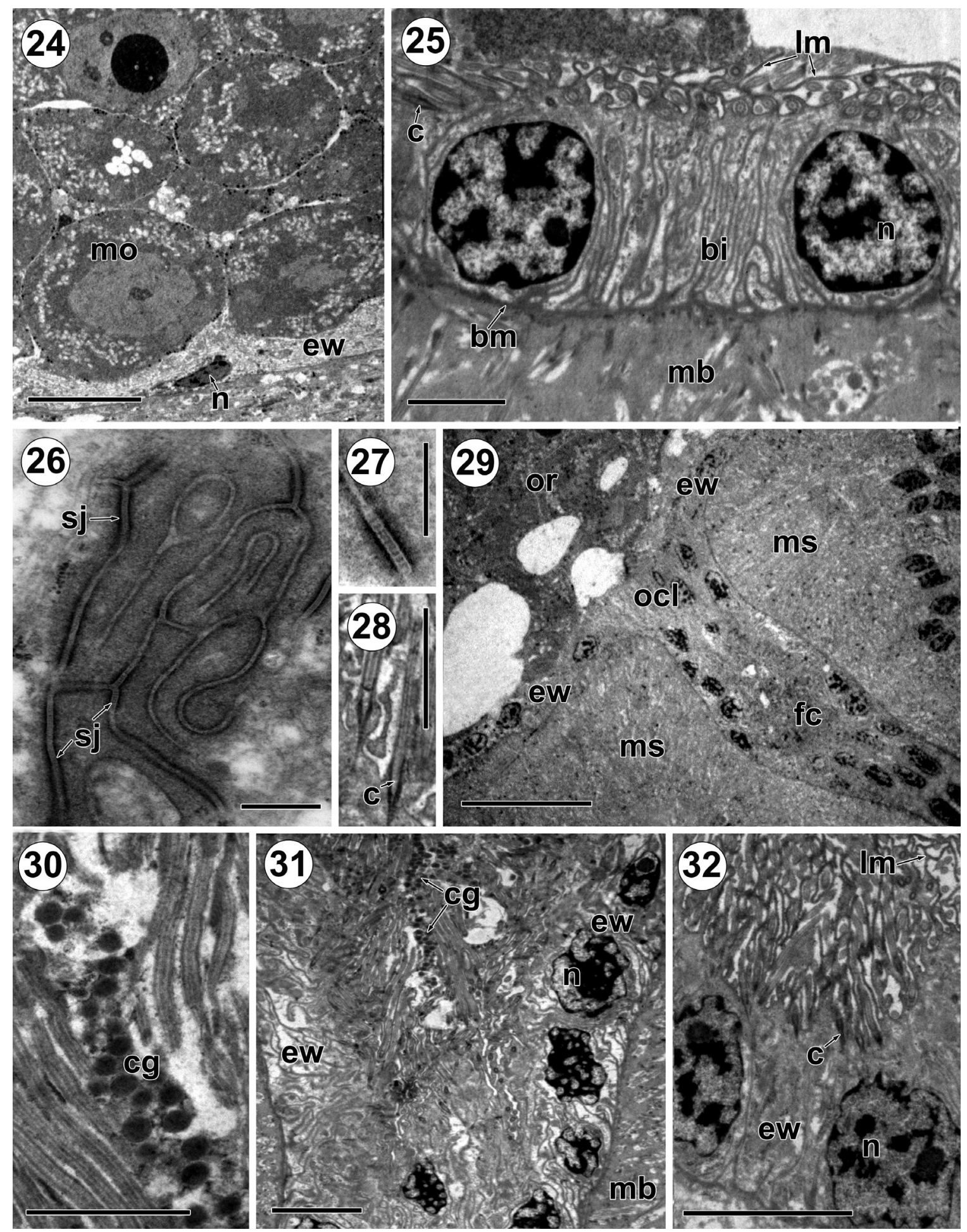

Figs. 24-32. Ultrastructure of the collecting ducts, ovarian receptacle, oocapt and fertilisation canal of Gyrocotyle urna. Fig. 24. Portion of a collecting oviduct showing the epithelial wall with the nucleus and mature oocytes within its lumen. Fig. 25. Epithelial wall of the ovarian receptacle showing the intraepithelial nucleus and apical cilia and lamellae. Fig. 26. Epithelial wall of the main collecting duct showing zone of the septate junctions. Fig. 27. Septate junction of the zone. Fig. 28. Surface cilia of the ovarian receptacle, oocapt and fertilisation canal. Fig. 29. Median line of the ovarian receptacle showing the oocapt with its muscular sphincter and a portion of the fertilisation canal. Fig. 30. Fertilisation canal lumen showing free cortical granules. Fig. 31. Fertilisation canal showing two epithelial walls and free cortical granules within lumen. Fig. 32. Epithelial wall of the distal portion of the fertilisation canal with apical lamellae and cilia. Abbreviations: bi - basal invaginations; bm - basal matrix; c - cilia; cg - cortical granules; ew - epithelial wall; fc - fertilisation canal; $1 \mathrm{~m}$ - lamellae; $\mathrm{mb}$ - muscle bundles; mo - mature oocyte; ms - muscular sphincter; $\mathrm{n}$ - nucleus; ocl - oocapt lumen; or - ovarian receptacle; sj - septate junction. Scale bars: Fig. $24=10 \mu \mathrm{m}$; Figs. $25,28,30=2 \mu \mathrm{m}$; Fig. $26=0.5 \mu \mathrm{m}$; Fig. $27=0.2 \mu \mathrm{m}$; Fig. $29=20 \mu \mathrm{m}$; Figs. $31,32=5 \mu \mathrm{m}$. 
differs from that of the Monogenea and the Eucestoda. In the presence of the lamellae and cilia on the surface of the ovarian receptacle, oocapt and fertilisation canal as well as the septate junction zones within collecting ducts, the oviducts of Gyrocotyle resemble those of the Digenea.

\section{Phylogenetic remarks}

The neoophoran type of the female gonad is present in neodermates. Nevertheless, the pattern of the ovarian and oviduct arrangements of G. urna described above is unique among the Neodermata. The division of the ovary into separated parts with their own collecting ducts as that present in Gyrocotyle has been observed only in species of the basal monogenean family Chimaericolidae of $G y$ rocotyle, which supports the suggestion by Bychowsky (1957) of an intermediate evolutionary position of the Gyrocotylidea between the Monogenea and Cestoda within the Cercomeromorphae. Among the Neoophora some Proseriata and some Fecampiidae have an arrangement of the ovary in the form of isolated follicles and collecting ducts. Recent molecular phylogenetic studies have shown that Adiaphanida (including Prolecitophora, Tricladida and Fecampiidae) are a sister taxon to the Neodermata, but Proseriata appear to be basal to Neodermata and Adiaphanida (Lockyer et al. 2003, Willems et al. 2006, Littlewood 2008).

Acknowledgements. The authors are grateful to Dr. G.A. Bristow, University of Bergen, Norway, for the possibility to collect material of Gyrocotyle urna in the North Sea. The present study was supported by the Russian Foundation for Fundamental Research project No. 09-04-00342a to L.G.P. and by a grant from the German Science Council (Deutsche Forschungsgemeinschaft) to W.E.R.X. (XY 12/5-1). R.K. and T.S. were financially supported by the Grant Agency of the Czech Republic (project No. 524/08/0885), Grant Agency of the Academy of Sciences of the Czech Republic (project No. KJB600960902) and the Institute of Parasitology (projects Z60220518 and LC522). The authors would also like to thank the staff of the Centre of Electron Microscopy, Institute of Biology of Inland Waters, Borok, Russia for the technical assistance. Thanks are due to Dr. V.D. Gulyaev, Institue of Animal Systematics and Ecology, RAS, Novosibirsk for his valuable comments.

\section{REFERENCES}

Allison F.R., Coakley A. 1973: The two species of Gyrocotyle in the Elephant fish, Callorhychus milii (Bory). J. R. Soc. N.Z. 3: 381-392.

Awad A.H.H., Probert A.J. 1990: Scanning and transmission electron microscopy of the female reproductive system of Schistosoma margrebowiei Le Roux, 1933. J. Helminthol. 64: 181-192.

BANDONI S.M., BRooks D.R. 1987: Revision and phylogenetic analysis of the Amphilinidea Poche, 1922 (Platyhelminthes: Cercomeria: Cercomeromorpha). Can. J. Zool. 65: 1110-1128.

Buörkman N., Thorsell W. 1964: On the ultrastructure of the ovary of the liver fluke Fasciola hepatica L. Z. Zellforsch. 63: 538-549.

Bychowsky B.E. 1957: [The Monogenea, Their Systematics and Phylogeny]. Izd. Akad. Nauk SSSR, Moscow - Leningrad, 509 pp. (In Russian.)

Campbell R.A., Gartner J.V. 1982: Pistana eurypharygis gen. et sp. n. (Cestoda: Pseudophyllidea) from the bathypelagic gulper eel, Eurypharynx pelecanoides Vaillant, 1982, with comments on host and parasite ecology. Proc. Helminthol. Soc. Wash. 49: 218-225.

Cifrian B., Martinez-Alos S., Gremigni V. 1993: Ultrastructural and cytochemical studies on the germarium of Dicrocoelium dendriticum (Plathelminthes, Digenea). Zoomorphology 113: $165-171$.

CoIL W.H. 1987: The oogenotop of Amphilina bipunctata (Cestodaria). Parasitol. Res. 73: 75-79.

Conn D.B. 1993: Ultrastructure of the gravid uterus of Hymenolepis diminuta (Platyhelminthes: Cestoda). J. Parasitol. 79: 583-590.

Conn D.B. 2000: Atlas of Invertebrate Reproduction and Development. Wiley-Liss, Inc., New York, 300 pp.

Conn D.B., MŁocicki D., Świderski Z. 2009. Ultrastructure of the early gravid uterus of Corallobothrium fimbriatum (Cestoda: Proteocephalidea). Parasitol. Res. 105: 989-996.
Davies R.E., Roberts L.S. 1983: Platyhelminthes - Eucestoda. In: K.G. Adiyodi and R.G. Adiyodi (Eds.), Reproductive Biology of Invertebrates, Vol. I. Oogenesis, oviposition and oosorption. Wiley, Chichester, pp. 109-233.

Davydov V.G., Poddubnaya L.G., Kolesnikova G.A. 1994: U1trastructure of genital system ducts of Caryophyllaeus laticeps (Cestoda, Caryophyllidea). Parazitologiya 28: 501-509. (In Russian.)

Dienske H. 1968: A survey of the metazoan parasites of the rabbitfish, Chimaera monstrosa L. (Holocephali). Neth. J. Sea Res. 4: 32-58.

Douglas L.T. 1963: The development of organ systems in nematotaeniid cestodes. III. Gametogenesis and embryonic development in Baerietta diana and Distoichometra kosloffi. J. Parasitol. 49: 530-558.

Dubinina M.N. 1982: [Parasitic worms of the class Amphilinida (Plathelminthes).] Trudy Zool. Inst., Leningrad, Vol. 100, 144 pp. (In Russian.)

El-Naggar M.M., Khidr A.A., Kearn G.C. 1990: Ultrastructural observations on the oviduct, Mehlis' glands and ootype of the monogenean Cichlidogyrus halli typicus (Price \& Kirk, 1967) Paperna, 1979. Int. J. Parasitol. 20: 203-209.

ERASmus D.A. 1973: A comparative study of the reproductive system of mature, immature and 'unisexual' female Schistosoma mansoni. Parasitology 67: 165-183.

Falleni A., Gremigni V. 1992: An ultrastructural study of growing oocytes in Nematoplana riegeri (Platyhelminthes). J. Submicrosc. Cytol. Pathol. 24: 51-59.

FAlleni A., LucChesi P. 1992: Ultrastructural and cytochemical aspects of oogenesis in Castrada viridis (Platyhelminthes, Rhabdocoela). J. Morphol. 213: 241-250.

Falleni A., Lucchesi P., Gremigni V. 1998: Ultrastructure of the female gonad of two temnocephalids (Platyhelminthes, Rhabdocoela). Hydrobiologia 383: 215-226.

Funrmann O. 1931: Dritte Klasse des Cladus Platyhelminthes: Cestoidea. In: W. Kükenthal and T. Krumbach (Eds.), Küken- 
thal's Handbuch der Zoologie, Walter de Gruyter \& Co., Berlin and Leipzig, Germany, pp. 141-416.

Galaktionov K.V., Dobrovolskis A.A. 2003: The Biology and Evolution of Trematodes. An Essay on the Biology, Morphology, Life Cycles, Transmissions, and Evolution of Digenetic Trematodes. Kluwer Academic Publishers, Boston/Dordrecht/ London, $575 \mathrm{pp}$.

Gibson D.I. 1996: Trematoda. In: L. Margolis and Z. Kabata (Eds.), Guide to the Parasites of Fishes of Canada. Part IV. Canadian Special Publication of Fisheries and Aquatic Sciences 124. NRC Press, Ottawa, pp. 1-373.

Grant W.C., Harkema R., Muse K.E. 1977: Ultrastructure of Pharyngostomoides procyonis Harkema, 1942 (Diplostomatidae). II. The female reproductive system. J. Parasitol. 63: 1019-1030.

GREMIGNI V. 1988: A comparative ultrastructural study of homocellular and heterocellular female gonads in free-living Platyhelminthes - Turbellaria. Fortschr. Zool. 36: 245-261.

Gremigni V., Nigro M. 1984: Ultrastructural study of oogenesis in Monocelis lineata (Turbellaria, Proseriata). Int. J. Invertebr. Reprod. Dev. 7: 105-118.

Gresson R.A. 1964: Oogenesis in the hermaphroditic Digenea (Trematoda). Parasitology 54: 409-421.

Grey R.D., Working P.K., Hedrick J.L. 1976: Evidence that the fertilization envelope blocks sperm entry in eggs of Хеnopus laevis: interaction of sperm with isolated envelopes. Dev. Biol. 54: $52-60$.

Gupta B.C., Parshad V.R., Guraya S.S. 1983: Morphological and histochemical observations on the oocapt and oviducal transport of oocytes in Paramphistomum cervi (Zeder, 1790) (Digenea: Trematoda). J. Helminthol. 57: 149-153.

GuRAYA S.S. 1969: Histochemical nature of cortical granules in the human egg. Z. Parasitenkd. 94: 32-35.

Halton D.W., Stranock S.D., Hardcastle A. 1976: Fine structural observations on oocyte development in monogeneans. Parasitology 73: 13-23.

Hathaway R.P. 1979: The morphology of crystalline inclusions in primary oocytes of Aspidogaster conchicola von Baer, 1827 (Trematoda: Aspidobothria). Proc. Helminthol. Soc. Wash. 46: 201-206.

Holy J.M., Wiтtrock D.D. 1986: Ultrastructure of the female reproductive organs (ovary, vitellaria, and Mehlis' gland) of Halipegus eccentricus (Trematoda: Derogenidae). Can. J. Zool. 64: $2203-2212$.

Joyeux C., Baer J.G. 1950: Le genre Gyrocotyloides Fuhrmann, 1931 (Cestodaria). Bull. Soc. Neuchâtel. Sci. Nat. 73: 71-79.

Justine J.-L., Mattei X. 1984: Ultrastructural observations on the spermatozoon, oocyte and fertilization process in Conapodasmius, a gonochoristic trematode (Trematoda, Digenea, Didymozoidae). Acta Zool. 65: 171-177.

Land J., Templeman W. 1968: Two new species of Gyrocotyle (Monogenea) from Hydrolagus affinis (Brito Capello) (Holocephali). J. Fish. Res. Board Can. 25: 2365-2386.

Littlewood D.T.J. 2008: Platyhelminth systematics and the emergence of new characters. Parasite 15: 333-341.

Lockyer A.E., Olson P.D., Littlewood D.T.J. 2003: Utility of complete large and small subunit rRNA genes in resolving the phylogeny of the Neodermata (Platyhelminthes): implications and a review of the cercomer theory. Biol. J. Linn. Soc. 78: 155-171.

Lucchesi P., Falleni A., Gremigni V. 1995: The ultrastructure of the germarium in some Rhabdocoela. Hydrobiologia 305: 207-212.
LyNCH J.E. 1945: Redescription of the species of Gyrocotyle from the ratfish, Hydrolacus colliei (Lay and Bennet), with notes on the morphology and taxonomy of the genus. J. Parasitol. 31: $418-446$.

Mackiewicz J.S. 1972: Caryophyllidea (Cestoidea): a review. Exp. Parasitol. 31: 417-512.

Olson P.D., Littlewood D.T.J., Bray R.A., Mariaux J. 2001: Interrelationships and evolution of the tapeworms (Platyhelminthes: Cestoda). Mol. Phylogen. Evol. 19: 443-467.

ORIDO Y. 1987: Development of the ovary and female reproductive cells of the lung fluke, Paragonimus ohirai (Trematoda: Troglotrematidae). J. Parasitol. 73: 161-171.

ORIDO Y. 1988: Fertilization and oogenesis of the lung fluke, Paragonimus ohirai (Trematoda: Troglotrematidae). Int. J. Parasitol. 18: 973-980.

Poddubnaya L.G., Bruňanská M., Kuchta R., Scholz T. 2006: First evidence of the presence of microtriches in the Gyrocotylidea. J. Parasitol. 92: 703-707.

Poddubnaya L.G., Gibson D.I., Olson P.D. 2007: Ultrastructure of the ovary, ovicapt and oviduct of the spathebothriidean tapeworm Didymobothrium rudolphii (Monticelli, 1890). Acta Parasitol. 52: 127-134.

Poddubnaya L.G., Kuchta R., Levron C., Gibson D.I., Scholz T. 2009: The unique ultrastructure of the uterus of the Gyrocotylidea Poche, 1926 (Cestoda) and its phylogenetic implications. Syst. Parasitol. 74: 81-93.

Poddubnaya L.G., Mackiewicz J.S., Bruňanská M., Scholz T. 2005a: Ultrastructural studies on the reproductive system of progenetic Diplocotyle olrikii (Cestoda: Spathebothriidea): ovarian tissue. Acta Parasitol. 50: 199-207.

Poddubnaya L.G., Mackiewicz J.S., Bruňanská M., Scholz T. 2005b: Fine structure of the female reproductive ducts of Cyathocephalus truncatus (Cestoda: Spathebothriidea), from salmonid fish. Folia Parasitol. 52: 323-338.

Poddubnaya L.G., Scholz T., Kuchta R., Levron C., Gibson D.I. 2008: Ultrastructure of the surface structures and secretory glands of the rosette attachment organ of Gyrocotyle urna (Cestoda: Gyrocotylidea). Folia Parasitol. 55: 207-218.

Podvyaznaya I.M. 1990: Structure of the female system of Prosthodendrium ascidia (Trematoda, Lecithodendriidae). In: Parasitic and free-living Platyhelminthes: faunistics and morphology. Proc. Zool. Inst., Leningrad, Vol. 221: 61-78. (In Russian.)

Podvyaznaya I.M. 2003: Ultrastructural studies of the female reproductive system in a parasite of bats Allassogonoporus amphoraeformis (Digenea: Allassogonoporidae). Parazitologiya 37: 387-393.

ReEs F.G. 1979: The morphology and ultrastructure of the female reproductive ducts in metacercaria and adult of Cryptocotyle lingua (Creplin) (Digenea: Heterophyidae). Z. Parasitenkd. 60: $157-176$.

Ryвicka K. 1967: Embryogenesis in cestodes. Adv. Parasitol. 4: 107-186.

SChмidt G.D. 2000: CRC Handbook of Tapeworm Identification. CRC Press, Boca Raton, Florida, 675 pp.

Sopott-Ehlers B. 1986: Fine-structural characteristics of female and male germ cells in Proseriata Otoplanidae (Platyhelminthes). Hydrobiologia 132: 137-144.

SopotT-Ehlers B. 1991: Electron microscopical observations on vitellocytes and germocytes in Nematoplana coelogynoporoides (Platyhelminthes, Proseriata). Zoomorphology 110: 293-300.

Swanson C.P., Webster P.L. 1980: The Cell. Fourth Edition. Prentice-Hall, Inc., Englewood Cliffs, New Jersey, 303 pp. 
ŚWIDERSKi Z. 1976: Fertilization in Hymenolepis diminuta (Cestoda: Cyclophyllidea). In: B. Feldman-Musham (Ed.), Proceedings of the 6th European Congress on Electron Microscopy, 14-20 September, 1976, Jerusalem, pp. 311-312.

Świderski Z., Conn D.B. 1999: Ultrastructural aspects of fertilization in Proteocephalus longicollis, Inermicapsifer madagascariensis, and Mesocestoides lineatus (Platyhelminthes, Cestoda). Acta Parasitol. 44: 19-30.

Świderski Z., Conn D.B., Miquel J., MŁocicki D. 2004. Fertilization in the cestode Gallegoides arfaai (Mobedi et Ghadirian, 1977) Tenora et Mas-Coma, 1978 (Cyclophyllidea, Anoplocephalidae). Acta Parasitol. 49: 108-115.

Świderski Z., XYlander W. 2000: Vitellocytes and vitellogenesis in cestodes in relation to embryonic development, egg production and life cycle. Int. J. Parasitol. 30: 805-817.

Tappenden T., Kearn G.C., Evans-Gowing R. 1993: Fertilization and the functional anatomy of the germarium in the monogenean Entobdella soleae. Int. J. Parasitol. 23: 901-911.

Thulin J. 1982: Structure and function of the female reproductive ducts of the fish blood-fluke Aporocotyle simplex Odhner, 1900 (Digenea: Sanguinicolidae). Sarsia 67: 227-248.

Tyler A. 1965: The biology and chemistry of fertilization. Am. Natural. 99: 309-334.

Waeschenbach A., Webster B.L., Bray R.A., Littlewood D.T.J. 2007: Added resolution among ordinal level relationship of tapeworms (Platyhelminthes: Cestoda) with complete small and large subunit nuclear ribosomal RNA genes. Mol. Phylogen. Evol. 45: 311-325.

Wardle R.A., McLeod J.A. 1952: The Zoology of Tapeworms. Minnesota Press, Minneapolis, $780 \mathrm{pp}$.

WATSON E.E. 1911: The genus Gyrocotyle, and its significance for problems of cestode structure and phylogeny. Univ. Calif. Publ. Zool. 6: 353-468.
Willems W.R., Wallberg A., Jondelius U., Littlewood D.T.J., Backeljau T., Schockaert E.R., Artois T.J. 2006: Filling a gap in the phylogeny of flatworms: relationships within the Rhabdocoela (Platyhelminthes), inferred from 18S ribosomal DNA sequences. Zool. Scr. 35: 1-17.

Williams J.B. 1989: Ultrastructural studies on Kronborgia (Platyhelminthes: Fecampiidae): the oocyte of $K$. isopodicola, with comments on oocyte microvilli and chromatoid bodies. Int. J. Parasitol. 19: 207-216.

Williams J.B. 1990: Ultrastructural studies on Kronborgia (Platyhelminthes: Fecampiidae): observations on the genital system of the female K. isopodicola. Int. J. Parasitol. 20: 957-963.

Williams H.H., Colin J.A., Halvorsen O. 1987: Biology of gyrocotylideans with emphasis on reproduction, population ecology and phylogeny. Parasitology 95: 173-207.

XYLANDER W.E.R. 1987: Ultrastructural studies on the reproductive system of Gyrocotylidea and Amphilinidea (Cestoda). II. Vitellarium, vitellocyte development and vitelloduct of Gyrocotyle urna. Zoomorphology 107: 293-297.

Xylander W.E.R. 2001: The Gyrocotylidea, Amphilinidea and the early evolution of Cestoda. In: D.T.J. Littlewood and R.A. Bray (Eds.), Interrelationships of the Platyhelminthes, Taylor \& Francis, London, pp. 103-111.

Xylander W.E.R. 2005: The Gyrocotylidea. In: K. Rohde (Ed.), Marine Parasites. CSIRO-Publishing, Sydney, pp. 89-92.

Xylander W.E.R., Poddubnaya L.G. 2009: Ultrastructure of the neodermal sclerites of Gyrocotyle urna Grube and Wagener, 1852 (Gyrocotylidea, Cestoda). Parasitol. Res. 105: 1593-1601.

Zavarzin A.A., Kharasova A.D. 1982: [Basics of general cytology.] Publishing House 'Leningrad University', Leningrad, 239 pp. (In Russian.)

Accepted 12 March 2010 